\title{
The Use and Abuse of Mutual Fund Expenses
}

\author{
Todd Houge \\ Jay Wellman
}

\begin{abstract}
Prior research shows that mutual fund investors are often aware of up-front charges like sales loads, but they are less mindful of annual operating expenses, even though both types of fees lower overall performance. This study documents the historical trend and recent abuse of annual mutual fund expenses. As the industry becomes more adept at segmenting customers by level of investment sophistication, we claim that load mutual fund companies take advantage of this ability and charge higher expenses to their target customer: the lessknowledgeable investor. No-load fund companies, which tend to attract the more sophisticated investor, offer lower expenses. For example, over 2000-2004 the average annual expense ratio of load equity funds was 50 basis points higher than no-load equity funds. We show evidence of this widening cost disparity since the early 1990s among new and existing equity, bond, and index funds. We also document a growing abuse of sales distribution or $12 \mathrm{~b}-1$ fees among funds that are closed to new investors, almost all of which are load funds. Thus, load fund investors are more susceptible to paying higher expenses and receiving lower returns over time.
\end{abstract}

KEY WORDS: 12b-1 fees, asset management fees, expense ratios, mutual funds, sales loads

\section{Introduction}

Mutual funds provide investors with convenient access to professional asset management services and broad portfolio diversification. Investors can purchase funds that offer exposure to various financial markets such as stocks, bonds, or real estate. By pooling capital with many other investors, each

Todd Houge is an Assistant Professor of Finance at the University of Iowa.

Jay Wellman is an Assistant Professor of Finance at Binghamton University. mutual fund shareholder owns a fraction of a larger, well-diversified, and professionally managed portfolio. Fund investors also benefit from economies of scale. As total shareholder resources increase, transaction costs become a smaller portion of the total portfolio. This is particularly important since higher expenses directly reduce portfolio returns.

Given these benefits, mutual funds have been one of the fastest growing areas of the U.S. financial services industry. From total investments of just $\$ 47.6$ billion in 1970 , today the industry manages $\$ 8.1$ trillion across more than 8,000 different funds. The Investment Company Institute (2005) estimates that mutual fund ownership has also risen from 5.7\% of U.S. households in 1980 to $48.1 \%$ in 2004. In fact, mutual fund investments now comprise 19.5\% of all household financial assets and represent the largest type of financial intermediary.

One reason for the popularity of mutual funds is that the industry has successfully marketed these investments to consumers. In essence, mutual funds are part investment vehicle, part consumer product. Fund companies attempt to differentiate their funds by aggressively marketing historical performance, investment policy, and quality of service. Yet, a General Accounting Office (2000) report notes that unlike most consumer products, mutual funds rarely endeavor to compete on cost.

This study documents the historical trend and recent abuse of annual mutual fund expenses for certain investors. Over the last 15 years, the fund industry appears to have become very adept at segmenting customers by level of investment sophistication. Using a sample that includes all U.S. equity and bond mutual funds from 1970 to 2004, we provide evidence that less-knowledgeable investors pay consistently higher asset management fees than more-knowledgeable investors holding similar 
funds. This widening cost disparity is evident among new and existing equity, bond, and index funds.

Mutual funds are sold through two main distribution channels: directly from the fund underwriter or indirectly through a broker. We suggest that knowledgeable investors are more likely to purchase directly through a fund's underwriter, avoiding all sales commissions or "loads." Less-knowledgeable (or less confident) investors are more likely to seek assistance from a broker or financial advisor, who receives a commission for selling load funds to investors. Prior research has clearly shown that load funds do not outperform no-load funds; sales loads are a deadweight cost that reduces the returns earned by the investor. Thus, we use a fund's load as a proxy for investor sophistication.

While mutual fund investors are often aware of up-front charges like sales loads, research shows they are often less cognizant of annual operating expenses, even though both types of fees are deadweight costs. Barber et al. (2005) document a negative relation between fund flows and sales loads, but no relation between operating expenses and fund flows. Alexander et al. (1998) also find that fewer than one in five mutual fund investors could estimate the annual expenses for their holdings. Since mutual fund returns are reported net of annual operating expenses, they are easily missed by investors. When a fund gains or loses over $20 \%$ in a given year, it is easy to see how investors might focus on the volatility rather than the cost of their funds.

Once invested in a high expense fund, investors may be less willing to search for lower cost alternatives. With thousands of mutual funds offered by hundreds of fund families, sorting through the choices is daunting. Sirri and Tufano (1998) contend that when search costs are high, individual investors turn to rating services and periodicals for advice. They document that fund flows relate directly to the size of the fund complex and level of media attention received by the fund. Since most mutual fund advertising focuses on past performance rather than cost, funds that spend disproportionately on marketing and distribution will tend to attract the less-knowledgeable investors that rely on these publications.

While load funds had significantly lower expense ratios in the early years of the sample, we find that the reverse is now true. Over 2000-2004, the average annual expense ratio of load funds was 50 basis points higher than no-load funds, $1.17 \%$ versus $0.67 \%$. Although much of this increase results from the widespread use of sales distribution (12b-1) fees, we show that load funds also charge significantly higher expenses for core asset management and administrative services. These trends are even more evident among newly offered funds. For equity funds in their first year of operation, the average expense ratio charged by load funds is $1.68 \%$ compared to just $0.49 \%$ for no-load funds.

Index funds seek to passively mimic the performance of a specified market index and are a widely touted alternative to high cost mutual funds. Since no managerial skill is required to pilot such portfolios, index funds usually have low turnover and low expenses. Yet, we find that the average expense ratio for load index funds is a significant 36 basis points higher than for no-load index funds over 20002004.

If sales loads proxy for the level of investor sophistication, then load fund investors appear more susceptible to paying higher expenses over time. These investors essentially pay high fees for the privilege of having funds marketed to them. Yet, unlike other consumer products, higher mutual fund costs are not associated with higher quality. In fact, the opposite is true; all else equal, higher operating expenses lower fund returns. Using different share classes to segment customers by level of investment knowledge allows the fund industry to boost profits at the expense of less sophisticated investors. The dramatic increase in the number of mutual funds over the last two decades may be as much a response to the growth of industry profitability as to the demand from investors.

\section{Mutual fund sales loads and operating expense ratios}

The direct costs of distributing and operating a mutual fund are levied against fund shareholders. These costs fall within two broad categories of fees: sales loads and annual operating expense ratios, expressed as a percentage of total fund assets. Funds are required to report their expenses in the prospectus using a standardized format.

Sales loads are one-time commissions frequently paid by investors who trade funds through a broker 
or financial advisor. The load is expressed as a percentage deducted from the value of the investment. The maximum allowable sales load is $8.50 \%$. Frontend loads are paid at the time when shares are purchased. Back-end loads are redemption fees charged when fund shares are sold. Investors who purchase shares directly from a fund's underwriter generally do not incur sales loads. These funds are referred to as no-load funds.

Barber et al. (2005) note that $91 \%$ of U.S. equity mutual fund assets were invested in front-end loaded funds in 1962, with an average fee above 8\%. The growth and popularity of no-load funds put downward pressure on sales loads starting in the mid1970s. Loads declined steadily throughout the 1980s and early 1990s. By 1999 just 35\% of equity funds charged a front-end load, with an average fee of about $5 \%$.

Mutual funds charge annual operating expenses to cover the administrative costs associated with managing the portfolio. These fees can range from just a few basis points to over $2 \%$ of fund assets. Mutual fund expense ratios consist of three components: management fees, 12b-1 fees (also called distribution or service fees), and other expenses. Management fees are viewed as the cost of managing and operating the portfolio. The $12 \mathrm{~b}-1$ fees are marketing costs named after an SEC rule that allows funds to pass along marketing or distribution costs such as advertising expenses and brokerage commissions to shareholders. Maximum 12b-1 fees are capped at $0.75 \%$ plus an additional $0.25 \%$ annual service fee. Funds that charge more than $0.25 \%$ in annual $12 b-1$ fees are not allowed to advertise themselves as noload funds. The "other" administrative expenses include legal, accounting, reporting, and director fees.

The adoption of rule 12b-1 in October 1980 remains one of the most controversial areas of mutual fund governance. According to Walsh (2004), the fund industry's original justification for 12b-1 fees was that such fees help to attract new shareholders into funds through advertising and by providing incentives for brokers to market the fund. Walsh reports that while funds with $12 \mathrm{~b}-1$ fees grow faster than funds without them, shareholders do not obtain the promised benefits from economies of scale in the form of lower average expenses. She argues that fund shareholder pay the cost of mar- keting the fund, while the fund's underwriter reaps most of the benefits of the fund's growth. We suggest that adoption of rule $12 \mathrm{~b}-1$ fees established the mechanism which allows the industry to segment its customers by level of sophistication and charge higher fees to those less-knowledgeable investors.

\section{Mutual fund data and empirical results}

The mutual fund data comes from the Center for Research in Security Prices (CRSP) Survivor BiasFree U.S. Mutual Fund Database. The sample includes all surviving and non-surviving funds that invest in either U.S. stocks or bonds. We exclude international funds, money market funds, and sector funds. Equity (bond) funds must invest at least $80 \%$ of its portfolio in stocks (bonds) to be included in the sample for a given calendar year. The final sample contains 80,708 fund years (46,648 equity funds and 34,060 bond funds) from 1970 to 2004.

Figure 1 presents equally weighted and total net asset (TNA) weighted average expense ratios for equity and bond funds over 1970-2004. Expense ratios include management fees, $12 \mathrm{~b}-1$ fees, and other expenses. The TNA weighted expense ratios increased for both equity and bond funds between 1970 and the early 1990s before declining slightly over the last decade of the sample. For equity funds, TNA weighted expenses peak in 1994 at $0.99 \%$, but fall to $0.84 \%$ in 2004 . Bond fund expenses hit their peak in 1990 with a TNA weighted average of $1.01 \%$ before falling to $0.67 \%$ in 2004 .

The long-term trends reported in Figure 1 are consistent with those identified by Barber et al. (2005) and Houge and Loughran (2006). The average expense ratio paid by equity and bond fund investors steadily rose for decades. Yet, the recent decline in TNA weighted expenses implies a shift among mutual fund investors toward lower cost funds. This change is consistent with the notion that fund investors are slowly becoming more aware of the negative impact of fund expenses on performance. Despite the growing demand for low-cost equity and bond funds, equally weighted average expense ratios continue to rise. This divergence suggests that fund companies continue to introduce new equity and bond funds with disproportionately higher operating expenses. 

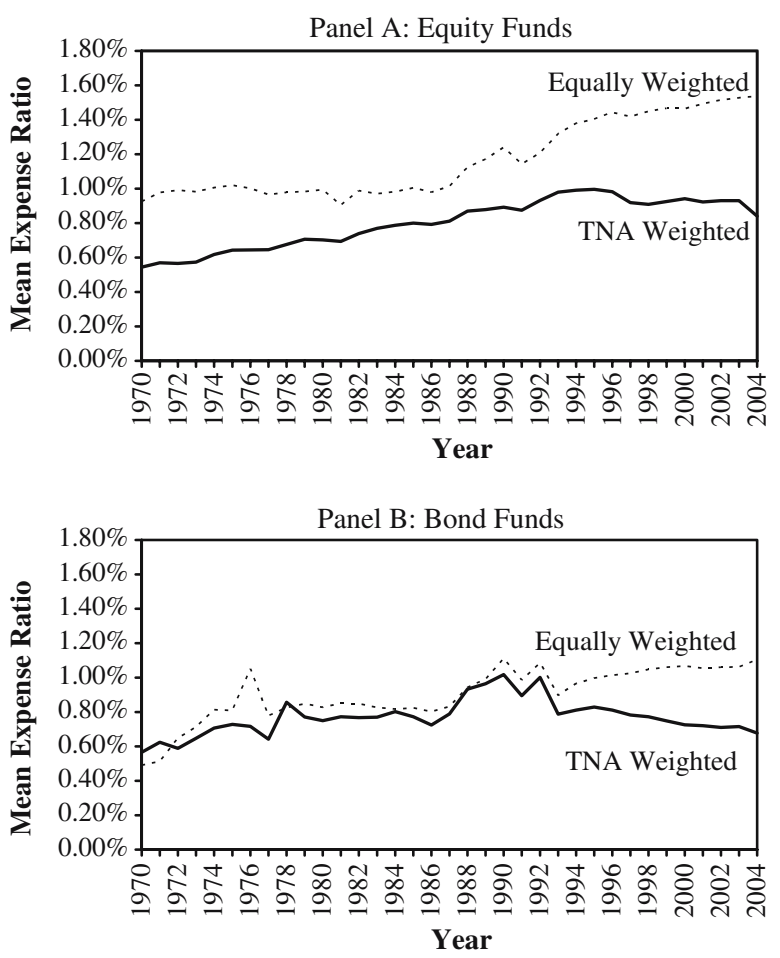

Figure 1. TNA weighted and equally weighted expense ratios of equity and bond mutual funds, 1970-2004. Source: CRSP Survivor-Bias Free U.S. Mutual Fund Database. Note: The sample includes all surviving and non-surviving funds that invest in either U.S. stocks or bonds. International funds, money market funds, and sector funds are excluded. Equity (bond) funds include funds investing at least $80 \%$ of their portfolio in U.S. equities (bonds). TNA is the total net assets of the fund. The expense ratio includes management fees, 12b-1 fees, and other expenses.

Figure 2 plots the TNA weighted average expense ratios of equity and bond funds by sales load. Interestingly, load equity funds in Panel A had significantly lower expense ratios than no load funds over the first 20 years of the sample. We find a similar, although less consistent, relationship across the bond funds in Panel B. The lower expense ratio of load funds was prevalent for up to 10 years after the 1980 adoption of rule 12b-1. After 1990, we see a very different story. Load fund expenses increase sharply for both equity and bond funds, while no-load fund expenses decrease. This period appears to indicate a shift in the marketing of load and noload funds to investors.

Figure 3 reveals the magnitude of the divergence between load and no-load fund expense ratios. Load equity funds in Panel A show average expenses that are 5-22 basis points lower than no-load equity funds over 1970-1988. The gap in expense ratios reverses after 1989. The average expense ratio of load equity funds is a statistically significant 21 basis points higher than no-load equity funds in 1992 and 54 basis points higher in 2004. We find similar trends for bond funds in Panel B. In the late 1980s, load bond funds carried significantly lower expenses than no-load bond funds, but experience a sharp reversal after 1989. Over the last 13 years of the sample, the expense ratios of load bond funds were
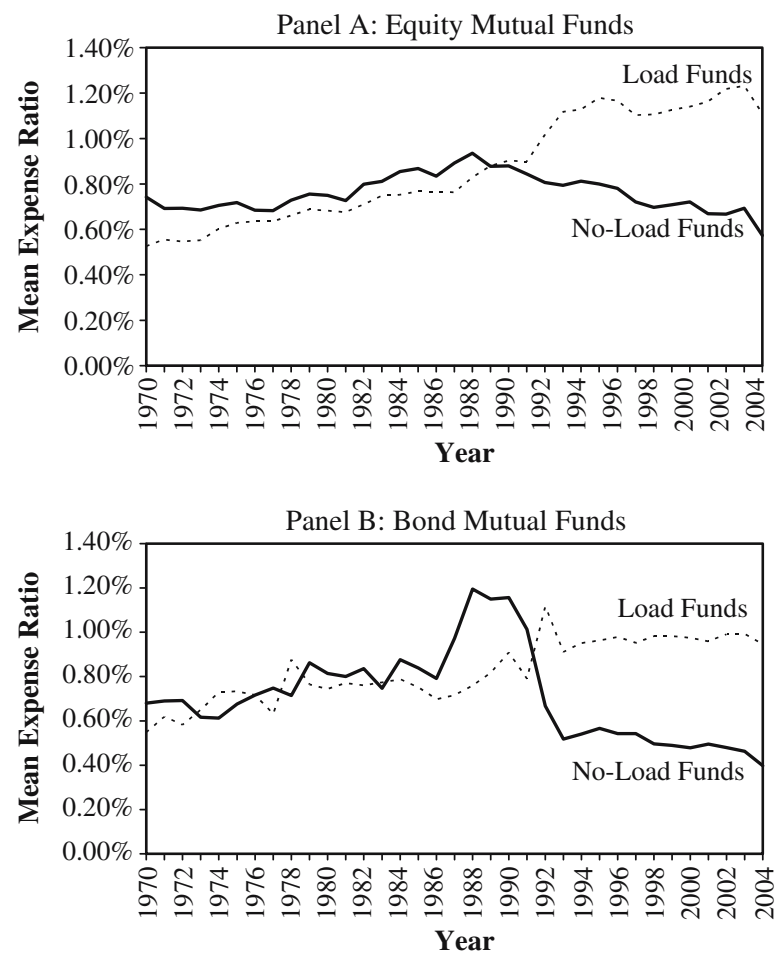

Figure 2. TNA weighted expense ratios of equity and bond mutual funds categorized by sales load, 19702004. Source: CRSP Survivor-Bias Free U.S. Mutual Fund Database Note: The sample includes all surviving and non-surviving funds that invest in either U.S. stocks or bonds. International funds, money market funds, and sector funds are excluded. Equity (bond) funds include funds investing at least $80 \%$ of their portfolio in U.S. equities (bonds). TNA is the TNAs of the fund. The expense ratio includes management fees, 12b-1 fees, and other expenses. Load funds include all funds charging a front or rear sales load or any fund charging $12 b-1$ fees of over 25 basis points per year. 

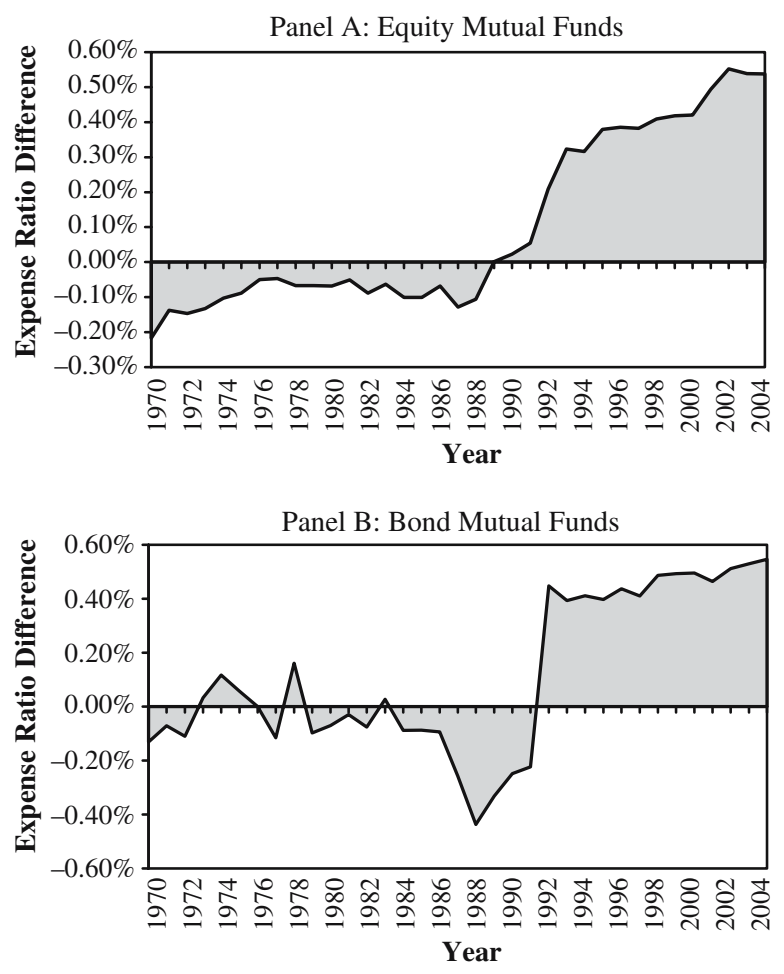

Figure 3. TNA weighted expense ratios of load funds minus no-load funds, 1970-2004. Source: CRSP Survivor-Bias Free U.S. Mutual Fund Database Note: The sample includes all surviving and non-surviving funds that invest in either U.S. stocks or bonds. International funds, money market funds, and sector funds are excluded. Equity (bond) funds include funds investing at least $80 \%$ of their portfolio in U.S. equities (bonds). TNA is the total net assets of the fund. The expense ratio includes management fees, $12 b-1$ fees, and other expenses. Load funds include all funds charging a front or rear sales load or any fund charging $12 b-1$ fees of over 25 basis points per year.

between 39 and 55 basis points higher than no-load bond funds.

Table I tests the difference in expenses between load and no-load funds for five-year periods beginning in 1970. Over the first four periods in Panel A, load equity funds have significantly lower expenses than no-load equity funds. Load fund expenses are significantly higher over the last three periods. These differences are all statistically significant at the 1\% level. Load bond fund expenses in Panel B, although generally lower than no-load bond fund expenses, are not statistically different for 1970-1984. From 1985 to 1989, however, load bond funds have sig- nificantly lower expenses: $0.76 \%$ versus $1.09 \%$ for no-load bond funds. This difference reverses dramatically over the final three periods, as load bond fund expenses significantly exceed those of no-load bond funds by 29,45 , and 51 basis points per year, respectively.

Sales loads, as a proxy for investor sophistication, allow fund companies to segment customers and potentially extract higher fees from less-knowledgeable investors. While firms often face difficulty raising the expense ratio of an existing fund, they have much greater flexibility when issuing a new fund. If fund companies compete on cost, then we would expect new funds to report lower expense ratios over time. Thus, expense ratio trends among newly issued funds indicate the emphasis of the industry. Panels C and D of Table I present average expenses for equity and bond funds in their first year reporting on the CRSP database. Prior to 1990, the number of newly created funds each year is fairly small, so we focus our analysis on the last 15 years of the sample period.

We find an even greater cost disparity among newly issued load and no-load funds over 19902004. Across the three time periods, the expense ratios of new load equity funds in Panel $\mathrm{C}$ average 36,89 , and 119 basis points higher than new no-load equity funds. These differences are highly significant at the $1 \%$ level. While the average cost of new load equity funds increased by over 30 basis points, the cost of new no-load equity funds actually fell by more than 50 basis points. We observe similar differences between new load and no-load bond fund expenses in Panel D. New load bond funds cost investors an average of 75,50 , and 60 basis points per year more than new no-load bond funds across the three time periods, respectively.

To be fair, however, it is worth noting that new no-load funds were significantly larger than new load funds: twice the size over 1995-1999 (\$84.2 million versus $\$ 41.0$ million) and five times the size over 2000-2004 (\$196.4 million versus $\$ 43.8$ million). Yet, the industry opened twice as many new load funds as no-load funds in 20002004, so it appears that some of this size differential was self-selected.

Index funds are one area we expect to find very little differential between the cost of load and no-load funds. The primary advantage of 


\section{TABLE I}

TNA weighted average expense ratios for equity and bond mutual funds categorized by sales load, 1970-2004

\begin{tabular}{|c|c|c|c|}
\hline Period & No-load funds (\%) & Load funds (\%) & Difference (\%) \\
\hline \multicolumn{4}{|c|}{ Panel $A$ : Equity funds } \\
\hline $1970-1974$ & 0.70 & 0.55 & $-0.15^{\star}$ \\
\hline 1975-1979 & 0.72 & 0.65 & $-0.07^{\star}$ \\
\hline 1980-1984 & 0.80 & 0.72 & $-0.08^{\star}$ \\
\hline 1985-1989 & 0.88 & 0.81 & $-0.07^{\star}$ \\
\hline 1990-1994 & 0.82 & 1.06 & $0.24^{\star}$ \\
\hline 1995-1999 & 0.73 & 1.13 & $0.40^{\star}$ \\
\hline $2000-2004$ & 0.67 & 1.17 & $0.50^{\star}$ \\
\hline \multicolumn{4}{|c|}{ Panel B: Bond funds } \\
\hline 1970-1974 & 0.64 & 0.64 & 0.00 \\
\hline 1975-1979 & 0.74 & 0.74 & -0.00 \\
\hline 1980-1984 & 0.82 & 0.77 & -0.05 \\
\hline 1985-1989 & 1.09 & 0.76 & $-0.33^{\star}$ \\
\hline 1990-1994 & 0.63 & 0.94 & $0.29^{\star}$ \\
\hline 1995-1999 & 0.52 & 0.97 & $0.45^{\star}$ \\
\hline $2000-2004$ & 0.46 & 0.97 & $0.51^{\star}$ \\
\hline \multicolumn{4}{|c|}{ Panel C: New equity funds } \\
\hline 1990-1994 & 1.01 & 1.37 & $0.36^{\star}$ \\
\hline 1995-1999 & 0.82 & 1.71 & $0.89^{\star}$ \\
\hline $2000-2004$ & 0.49 & 1.68 & $1.19^{\star}$ \\
\hline \multicolumn{4}{|c|}{ Panel D: New bond funds } \\
\hline 1990-1994 & 0.59 & 1.34 & $0.75^{\star}$ \\
\hline 1995-1999 & 0.69 & 1.19 & $0.50^{\star}$ \\
\hline $2000-2004$ & 0.51 & 1.11 & $0.60^{\star}$ \\
\hline \multicolumn{4}{|c|}{ Panel E: Equity index funds } \\
\hline 1995-1999 & 0.19 & 0.50 & $0.31^{\star}$ \\
\hline $2000-2004$ & 0.19 & 0.55 & $0.36^{\star}$ \\
\hline
\end{tabular}

$\star$ Statistically significant at the $1 \%$ level.

$\star \star$ Statistically significant at the $5 \%$ level.

$\star \star \star$ Statistically significant at the $10 \%$ level.

Source: CRSP Survivor-Bias Free U.S. Mutual Fund Database.

Note: The sample includes all surviving and non-surviving funds that invest in either U.S. stocks or bonds. International funds, money market funds, and sector funds are excluded. Equity (bond) funds include funds investing at least $80 \%$ of their portfolio in U.S. equities (bonds). TNA is the total net assets of the fund. The expense ratio includes management fees, 12b-1 fees, and other expenses. Load funds include all funds charging a front or rear sales load or any fund charging 12b-1 fees of over 25 basis points per year. New funds are funds in their first year of existence in the CRSP database. Index funds were selected on the basis of having the word "Index" or its abbreviation in the fund's name.

index investing is tracking the performance of a benchmark index at a low cost. We examine the expense ratios of equity index funds in Panel E of Table I. Since few bond index funds are available, we limit our sample to only equity index funds, which gained popularity in the mid-1990s. Again the story is similar: load funds are significantly more expensive.
For example, the average expense ratio of no-load index funds from 2000 to 2004 is a mere 19 basis points, compared to 55 basis points for load index funds. Even among these low-cost vehicles, load fund investors pay higher fees than no-load investors.

Why do we see such sharp increases in load fund expense ratios in recent years? The increased use of 
TABLE II

Total net asset weighted 12b-1 and asset management fees for equity, bond, and equity index funds categorized by sales load

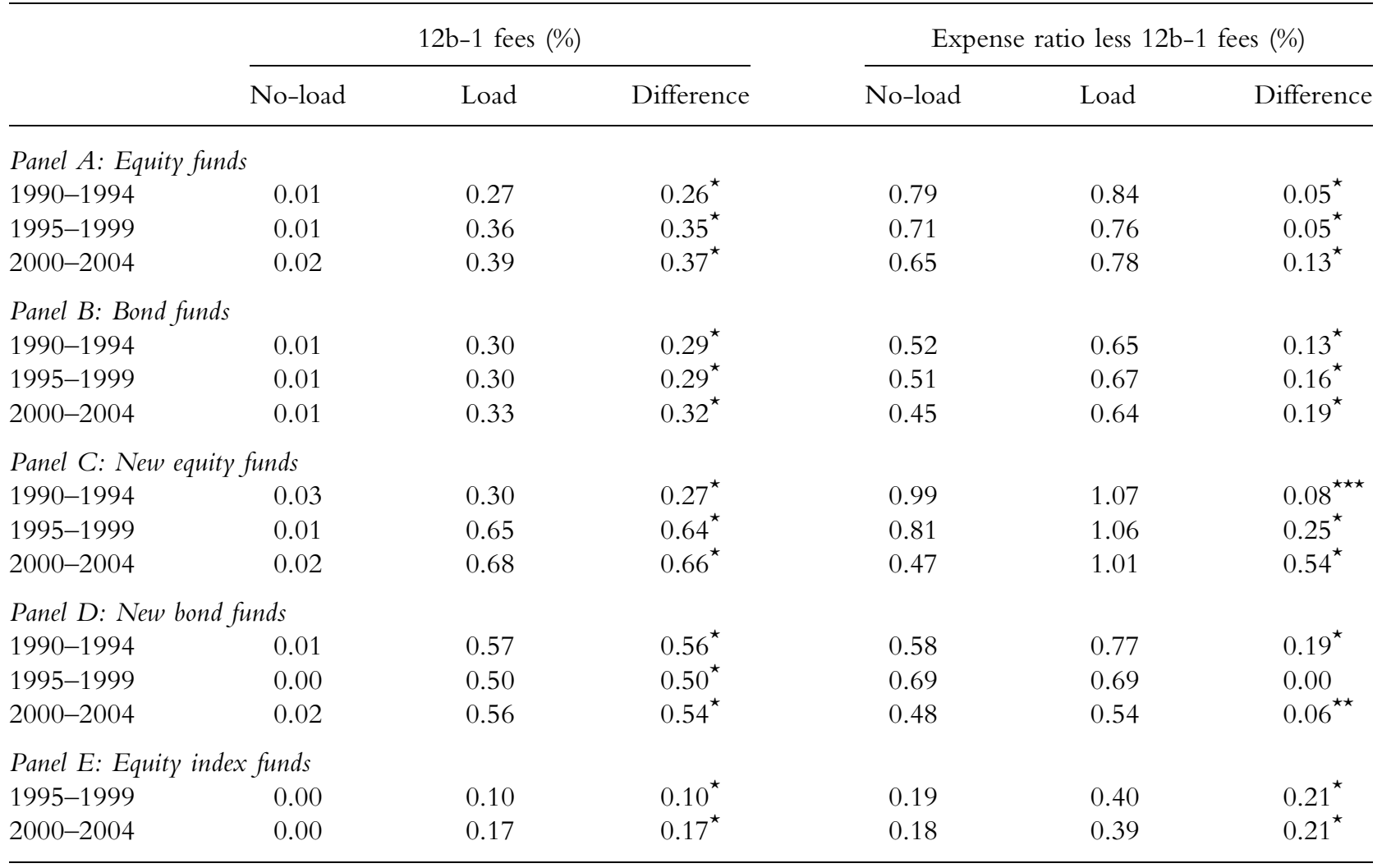

* Statistically significant at the $1 \%$ level.

$\star \star$ Statistically significant at the $5 \%$ level.

$\star \star \star$ Statistically significant at the $10 \%$ level.

Source: CRSP Survivor-Bias Free U.S. Mutual Fund Database.

Note: The sample includes all surviving and non-surviving funds that invest in either U.S. stocks or bonds. International funds, money market funds, and sector funds are excluded. Equity (bond) funds include funds investing at least $80 \%$ of their portfolio in U.S. equities (bonds). TNA is the total net assets of the fund. The expense ratio includes management fees, 12b-1 fees, and other expenses. Load funds include all funds charging a front or rear sales load or any fund charging 12b-1 fees of over 25 basis points per year. New funds are funds in their first year of existence in the CRSP database. Index funds were selected on the basis of having the word "Index" or its abbreviation in the fund's name. The 12b-1 fees are available on CRSP beginning in 1993. Asset management fees are calculated by subtracting the $12 \mathrm{~b}-1$ fee from a fund's expense ratio.

$12 \mathrm{~b}-1$ fees is a major factor. Over time the industry has regarded $12 \mathrm{~b}-1$ fees as a substitute for sales loads. The fund industry has also argued historically that 12b-1 fees are cost-neutral: assets of funds charging 12b-1 fees should increase due to higher broker motivation to sell such funds. As the size of the fund increases, the operating expenses will decrease to negate the size of the $12 \mathrm{~b}-1$ fee.
Instead, Ferris and Chance (1987) and Livingston and O'Neal (1998) show that 12b-1 fees are a deadweight loss to investors. McLeod and Malhotra (1994) and Malhotra and McLeod (1997) find that the deadweight loss from 12b-1 fees increases over the 1988-1993 period. Thus, while 12b-1 fees may provide an incentive for brokers to sell these funds, it appears that investors do not receive any of the 
TABLE III

Mutual funds closed to new investors that charge $12 \mathrm{~b}-1$ fees by year

\begin{tabular}{|c|c|c|c|c|c|}
\hline Year & Number of funds & Average TNA & Average expense (\%) & Average $12 b-1(\%)$ & Load funds $(\%)$ \\
\hline \multicolumn{6}{|c|}{ Panel A: Equity funds } \\
\hline 1995 & 0 & - & - & - & - \\
\hline 1996 & 0 & - & - & - & - \\
\hline 1997 & 0 & - & - & - & - \\
\hline 1998 & 1 & 541.7 & 1.26 & 0.25 & 0.0 \\
\hline 1999 & 6 & 754.3 & 1.47 & 0.54 & 50.0 \\
\hline 2000 & 9 & 380.4 & 1.65 & 0.64 & 66.7 \\
\hline 2001 & 34 & 265.7 & 1.88 & 0.68 & 79.4 \\
\hline 2002 & 78 & 302.2 & 1.82 & 0.66 & 78.2 \\
\hline 2003 & 116 & 418.7 & 1.88 & 0.65 & 79.3 \\
\hline 2004 & 119 & 412.8 & 1.88 & 0.65 & 79.8 \\
\hline \multicolumn{6}{|c|}{ Panel B: Bond funds } \\
\hline 1995 & 1 & 76.2 & 1.91 & 1.00 & 100 \\
\hline 1996 & 1 & 119.9 & 2.10 & 0.90 & 100 \\
\hline 1997 & 1 & 249.9 & 1.73 & 0.91 & 100 \\
\hline 1998 & 4 & 874.4 & 1.41 & 0.67 & 100 \\
\hline 1999 & 4 & 717.8 & 1.36 & 0.66 & 100 \\
\hline 2000 & 4 & 497.4 & 1.36 & 0.64 & 100 \\
\hline 2001 & 7 & 281.8 & 1.43 & 0.61 & 100 \\
\hline 2002 & 12 & 226.9 & 1.46 & 0.61 & 100 \\
\hline 2003 & 26 & 337.8 & 1.33 & 0.56 & 100 \\
\hline 2004 & 25 & 325.5 & 1.33 & 0.57 & 100 \\
\hline
\end{tabular}

Source: CRSP Survivor-Bias Free U.S. Mutual Fund Database.

Note: The sample includes all surviving and non-surviving funds that invest in either U.S. stocks or bonds. International funds, money market funds, and sector funds are excluded. Equity (bond) funds include funds investing at least $80 \%$ of their portfolio in U.S. equities (bonds). TNA is the total net assets of the fund. The expense ratio includes management fees, 12b-1 fees, and other expenses. Load funds include all funds charging a front or rear sales load or any fund charging $12 \mathrm{~b}-1$ fees of over 25 basis points per year.

suggested long-term benefits. Instead, these fees seem to merely increase the profits of the fund companies at the expense of shareholders.

Table II decomposes mutual fund operating expenses into asset management and $12 \mathrm{~b}-1$ fees. CRSP reports $12 \mathrm{~b}-1$ fees beginning in 1993. To estimate asset management fees, we subtract a fund's 12b-1 fee from its total expense ratio. We report TNA weighted expenses for new and existing equity, bond, and equity index funds categorized by sales load. The table shows the average $12 \mathrm{~b}-1$ fee for no-load funds is at or near zero. Not only are $12 \mathrm{~b}-1$ fees primarily limited to load funds, but also their use among equity funds appears to have increased substantially over time. The average $12 \mathrm{~b}-1$ fees of load equity funds have increased from 27 to 39 basis points since the early 1990s; for new load equity funds these fees jumped from 30 to 68 basis points over the same period. Load equity index funds do charge lower 12b-1 fees, but even those have increased over the sample, from 10 to 17 basis points.

The use of $12 b-1$ fees among load funds is clearly seen in our data. These fees are heavily discussed in the financial press. In contrast, mutual fund asset management fees garner considerably less attention. These fees cover the costs of operating and managing the portfolio. While differences in distribution networks may influence sales loads and $12 \mathrm{~b}-1$ fees, the cost of managing the underlying fund portfolio should be similar across load and no-load funds.

Table II also provides the average asset management expenses for load and no-load funds. Interestingly, load 
funds again charge categorically higher management fees than no-load funds. The differences are considerably smaller than with $12 \mathrm{~b}-1$ fees, yet are still generally significant at the $1 \%$ level. This disparity appears to either hold constant or get larger over time. Management expenses for both load and no-load funds surprisingly decline over the sample period; however, no-load funds appear to gain a larger share of this cost savings compared to similar load funds.

Cost differences increase from 5 to 13 basis points for equity funds (Panel A) and from 13 to 19 basis points for bond funds (Panel B). New equity funds (Panel C) see the largest increase in relative management fees between load and no-load funds during this period, growing from a marginally significant 8 basis points over 1990-1994 to 54 basis points over 2000-2004. Perhaps most enlightening is the difference in asset management expenses for equity index funds (Panel E). Management fees of load index funds are twice as high over 2000-2004 as noload index funds: 39 basis points versus 18, respectively. We cannot identify a financial reason why passive funds should have such categorically different management expenses.

Increasing 12b-1 fees do not imply that load funds have higher distribution costs. Rather, these fees are used instead of front- and back-end loads to pay for broker compensation. Although average sales loads have decreased roughly $3 \%$ over the past three decades, it appears that load funds use $12 \mathrm{~b}-1$ fees to shift these costs from up front, where investors see them clearly, to the annual expense ratio, where they do not.

A growing number of funds that have permanently or temporarily closed to new investors or new investments also continue to charge $12 \mathrm{~b}-1$ fees. In other words, these funds charge shareholders a fee for marketing and distributing the fund, even though the fund is closed to new investment. Not only are these charges unethical, but they are also a clear violation of the intended use of these fees as outlined in rule 12b-1.

We examine this issue in Table III. The CRSP database identifies active funds that are closed to new investors. The number of closed funds that continue to charge $12 \mathrm{~b}-1$ fees has increased significantly, particularly for equity funds. We identified only one closed fund with a 12b-1 fee in 1998, but 119 such funds by 2004. Closed equity and bond funds charged their investors average 12b-1 fees of 65 and 57 basis points for marketing and distribution costs in 2004, even though these funds were not open to new investors. The vast majority of these funds are load funds: nearly $80 \%$ of the equity funds and all $100 \%$ of the bond funds. These are not particularly small funds, either. These funds average hundreds of millions of dollars in total assets under management, which is near the median sized mutual fund over this period.

Under the directives of Rule 12b-1, a mutual fund's board of directors is obligated to regularly reevaluate the benefits of these fees to the fund's shareholders. Yet, many of the same close equity and bond funds show up in this sample year after year extracting unnecessary 12b-1 fees. By allowing this practice to continue, these boards breach their fiduciary duty to shareholders. Regulatory authorities are certainly aware of this practice, yet they also appear unwilling protect these fund investors by enforcing the law.

\section{Conclusion}

Mutual funds aggressively advertise historical performance but rarely compete on expenses. Even though these fees represent a deadweight cost on long-term returns, few investors can actually estimate the annual expenses of their fund holdings. We contend the fund industry has become very adept at segmenting customers by level of investment sophistication. The industry uses this ability to market high expense funds to less-knowledgeable customers. Once invested in these funds, investors may face high costs to search for a lower fee alternative, often inducing them to maintain the status quo.

Load funds consistently charge higher $12 \mathrm{~b}-1$ fees, asset management fees, and total expenses than their no-load counterparts, a clear sign that load and noload fund investors display different levels of sophistication. Over time the industry has regarded $12 \mathrm{~b}-1$ fees as a substitute for sales loads, shifting a portion of these up-front charges to the annual expense ratio where they are less likely to be noticed by investors. We also find growing abuse of sales distribution or $12 \mathrm{~b}-1$ fees by funds that are closed to new investors, almost all of which are load funds.

Market segmentation to provide different levels of customer service can be beneficial to investors. Market segmentation to extract higher fees from less-knowledgeable investors raises ethical concerns. The SEC is currently investigating one simple, yet 
potentially effective, solution. The proposal would require funds to disclose the dollar amount of operating expenses paid by each shareholder in a given year. While this change would not prevent mutual funds from charging high 12b-1 fees or operating expenses, it would arm investors with information necessary to make more informed mutual fund decisions.

Ironically, the increase in expense ratios of load funds undermines a key sales pitch often made by the brokerage industry. The industry argues that load funds are cheaper in the long run because they have lower annual expense ratios compared to no-load funds. While a sales load lowers an investor's performance initially, he or she would more than make up for that in the annual expense savings over time.

It is true that load funds did have lower expense ratios over 1970-1990. Whether they were low enough to allow investors to recoup the high loads of the time is unlikely, at least on average. Yet, one could argue that this was at least a noble lie, since it motivated investors to hold their mutual funds for the longterm and encouraged value-maximizing behavior.

The mutual fund industry seems to have currently embraced a path that generates the most profit with the least resistance from investors. This trend makes load funds an increasingly poor long-term investment, dependant on the unsophisticated investor for its continued success. Load fund shareholders often pay high fees to market and grow the fund, but the fund's advisor is the most likely beneficiary of this growth. As a whole, load funds are not serving investors well over time.

\section{Acknowledgements}

We thank Ann Tenbrunsel, a referee, and seminar participants at the Ethical Dimensions in Business: Reflections from the Business Academic Community conference at the University of Notre Dame for helpful comments and suggestions.

\section{References}

Alexander, G. J., J. D. Jones and P. J. Nigro: 1998, 'Mutual Fund Shareholders: Characteristics, Investor Knowledge, and Sources of Information', Financial Services Review 7, 301-316.
Barber, B. M., T. Odean and L. Zheng: 2005, 'Out of Sight, Out of Mind: The Effects of Expenses on Mutual Fund Flows', Journal of Business 78(6), 20952119.

Ferris, S. P. and D. M. Chance: 1987, 'The Effect of 12b1 Plans on Mutual Fund Expense Ratios: A Note', Journal of Finance 42(4), 1077-1082.

General Accounting Office: 2000, 'Mutual Fund Fees: Additional Disclosure Could Encourage Price Competition,' Washington, D.C. (GAO/GGD-00-126).

Houge, T. and T. Loughran: 2006, 'Do Investors Capture the Value Premium?' Financial Management, forthcoming.

Investment Company Institute: 2005, Investment Company Fact Book, 45th edition. Washington, DC.

Livingston, M. and E. S. O'Neal: 1998, 'The Cost of Mutual Fund Distribution Fees', Journal of Financial Research 21(2), 205-218.

Malhotra, D. K. and R. W. McLeod: 1997, 'An Empirical Analysis of Mutual Fund Expenses', Journal of Financial Research 20(2), 175-190.

McLeod, R. W. and D. K. Malhotra: 1994, 'A ReExamination of the Effect of 12B-1 Plans on Mutual Fund Expense Ratios', Journal of Financial Research 17(2), 231-240.

Sirri, E. R. and P. Tufano: 1998, 'Costly Search and Mutual Fund Flows', Journal of Finance 53(5), 15891622.

Walsh, L.: 2004, 'The Costs and Benefits to Fund Shareholders of 12b-1 Plans: An Examination of Fund Flows, Expenses, and Returns,' Office of Economic Analysis, United States Securities and Exchange Commission Working Paper.

Todd Houge

Tippie College of Business,

The University of Iowa, S288 PBB, Iowa City, IA, 52242-1994, U.S.A. E-mail:todd-houge@uiowa.edu

Jay Wellman A-316 School of Management Binghamton University Binghamton, NY, 13902, U.S.A. 